ISSN 0258-7122

Bangladesh J. Agril. Res. 39(2): 303-309, June 2014

\title{
EFFECT OF NITROGEN, PHOSPHORUS, POTASSIUM, AND SULPHUR ON THE GROWTH AND SEED YIELD OF CORIANDER (Coriandrum sativum $\mathbf{L}$.)
}

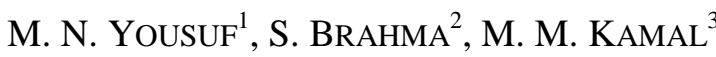 \\ S. AKTER ${ }^{4}$ AND M. E. K. CHOWDHURY ${ }^{5}$
}

\begin{abstract}
A field experiment was conducted at the Spices Research Centre, Shibgonj, Bogra, Bangladesh during the rabi seasons of 2008-2009 and 2009-2010 to determine the requirement of $\mathrm{N}, \mathrm{P}, \mathrm{K}$, and $\mathrm{S}$ of coriander (BARI Corinader-1) for achieving satisfactory seed yield of this crop. Different levels of nitrogen $(0$, $40,70$, and $100 \mathrm{~kg} / \mathrm{ha})$, phosphorus $(0,25,50$, and $70 \mathrm{~kg} / \mathrm{ha})$, potassium $(0,30$, 60 , and $90 \mathrm{~kg} / \mathrm{ha})$, and sulphur $(0,10,20$, and $30 \mathrm{~kg} / \mathrm{ha})$ were distributed in the plot. The experiment was tested in randomized complete block design with three replications. There was positive impact of application of those nutrients on the yield and yield contributing characters of coriander up to a moderate level of $\mathrm{N}_{70} \mathrm{P}_{50} \mathrm{~K}_{30} \mathrm{~S}_{20} \mathrm{~kg} / \mathrm{ha}$. The highest seed yield (2.06 t/ha in 2008-2009 and 2.09 $\mathrm{t} / \mathrm{ha}$ in 2009-2010) was obtained with this moderate application of $\mathrm{N}, \mathrm{P}, \mathrm{K}$, and $\mathrm{S}(70,50,30$, and $20 \mathrm{~kg} / \mathrm{ha}$, respectively) and yield was declined with higher doses of these elements. The fertilizer treatment $\mathrm{N}_{70} \mathrm{P}_{50} \mathrm{~K}_{30} \mathrm{~S}_{20}$ was observed to be the best suitable dose for coriander cultivation on Grey Terrace Soil of Amnura Soil Series under AEZ-25(Level Barind Tract) of Bangladesh.
\end{abstract}

Keywords: Coriander, growth, nitrogen, phosphorus, potassium, sulphur, seed yield.

\section{Introduction}

Coriander (Coriandrum sativum L.) belongs to the family Apiaceae is one of the earliest spices and used by mankind Luaza et al. (1996). The coriander plant gives two primary products that are used for flavouring purposes: the fresh green herb and the spice. The ordour and flavour of these two products are markedly different. The herb is used for culinary flavouring purposes in Asia, the Middle East, and Central and South America. The fruits are an important ingredient of curry powder (Ramadan et al., 2002). These are used as a pickling spice, in seasonings and sausages and also in pastries, buns, cakes, and other confectionary. Coriander oil is used to flavour alcoholic beverages, candies, meat, sauces, and tobacco. The fruits and oil are used to cover the taste or correct the nauseating or griping qualities of other medicines. They are used medicinally for a number of purposes, particularly to relieve flatulence Bhuiyan et al. (2009).

Significant effects were noticed on growth parameters like plant height, number of branches, leaf number, and fresh weight of coriander plants when

${ }^{1,3 \& 5}$ Scientific Officer, ${ }^{2}$ Senior Scientific Officer, ${ }^{4}$ Chief Scientific Officer, Spices Research Centre, Bogra, Bangladesh Agricultural Research Institute (BARI), Bangladesh. 
major nutrients like nitrogen, phosphorus, and potassium Aly (2002), Channabasavanna (2002), Tripathi et al. (2001) and Singh et al. (1999). Application of $\mathrm{N}_{80} \mathrm{P}_{60} \mathrm{~K}_{30} \mathrm{~kg} / \mathrm{ha}$ gave maximum plant height, leaf number, number of branches, fresh weight of plant and seed yield were optimum (Bhat et al., 1992). FYM@10-15 t/ha and $\mathrm{N}_{20} \mathrm{P}_{30} \mathrm{~K}_{20} \mathrm{~kg} / \mathrm{ha}$ was good for coriander in no irrigated area, in irrigated area, nitrogen increased to $50 \mathrm{~kg} / \mathrm{ha}$ Pruthi (2001). According to (Rahman et al., 2006), application of $\mathrm{N}_{80} \mathrm{P}_{24} \mathrm{~K}_{32} \mathrm{~S}_{10} \mathrm{~kg} / \mathrm{ha}$, the seed yield of coriander was highest. Jan et al. (2011) reported that application of 45 $\mathrm{kg} / \mathrm{ha}$ of $\mathrm{P}$ gave the highest seed yield (1.05 $\mathrm{t} / \mathrm{ha})$ of coriander in Pakistan.

So, considering the facts stated above, the present investigation was undertaken to evaluate the effects of application of different levels of nitrogen, phosphorus, potassium and sulphur on the yield and yield attributes of coriander.

\section{Materials and Method}

Field experiments were conducted at the Spices Research Centre, Shibgonj, Bogra on Grey Terrace Soil of Amnura Soil Series under AEZ-25 (Level Barind Tract) during 2008-2009 and 2009-2010. A description of some chemical properties of experimental soil collected from a depth of $0-15 \mathrm{~cm}$ prior to application of nitrogen, phosphorus, potassium, and sulphur are presented in Table 1. Soil analysis was determined by AS1 method (Hunter, 1984). The experiment was set up in a randomized complete block design (RCBD) with 14 treatment combinations having three replications. There were four levels of nitrogen $(0,40,70$, and $100 \mathrm{~kg} / \mathrm{ha})$, four levels of phosphorus $(0,25,50$ and 70 $\mathrm{kg} / \mathrm{ha}$ ), four levels of potassium $(0,30,60$, and $90 \mathrm{~kg} / \mathrm{ha})$, four levels of sulphur $(0,10,20$, and $30 \mathrm{~kg} / \mathrm{ha})$. A blanket dose of cowdung $5 \mathrm{t} / \mathrm{ha}, \mathrm{Zn}_{3}$, and $\mathrm{B}_{1.5} \mathrm{~kg} / \mathrm{ha}$ were applied in the experimental plots. The total amount of cowdung, TSP for P, MoP for $\mathrm{K}$, gypsum for $\mathrm{S}, \mathrm{ZnSO}_{4}$ for $\mathrm{Zn}$ and boric acid for $\mathrm{B}$ were applied during final land preparation. Urea for $\mathrm{N}$ was applied in 2 equal splits at 25 and 40 days after sowing. The unit plot size was $3 \mathrm{~m} \times 1.5 \mathrm{~m}$ and seeds of coriander (BARI Coriander-1) were sown at 12 November 2008 and 01 November 2009 and crop was harvested at its maturity on 28 February 2009 and 20 February 2010, respectively. Necessary intercultural operations were done throughout the cropping season for proper growth and development of the plant. Yield contributing parameters were recorded from ten randomly selected plants from each unit plot. The recorded data on different parameters were statistically analyzed by using MSTAT software to find out the significance of variation resulting from the experimental treatments. The difference between the treatment means were judged by Duncan's Multiple Range Test (DMRT) according to Gomez and Gomez, 1984. 
Table 1. Soil properties of the Ca experimental site during 2008-2009 and 2009-2010.

\begin{tabular}{|c|c|c|c|c|c|c|c|c|c|c|c|}
\hline \multirow{2}{*}{ Location } & \multirow{2}{*}{$\mathrm{pH}$} & \multirow{2}{*}{$\begin{array}{c}\mathrm{OM} \\
\%\end{array}$} & $\mathrm{Ca}$ & $\mathrm{Mg}$ & $\mathrm{K}$ & \multirow{2}{*}{$\begin{array}{l}\text { Total } \\
\text { N (\%) }\end{array}$} & $\mathrm{P}$ & S & B & $\mathrm{Mn}$ & $\mathrm{Zn}$ \\
\hline & & & \multicolumn{3}{|c|}{$\mathrm{Mq} / 100 \mathrm{~g}$} & & \multicolumn{5}{|c|}{$\mu \mathrm{g} / \mathrm{g}$} \\
\hline & \multicolumn{11}{|c|}{ 2008-2009 } \\
\hline \multirow{2}{*}{$\begin{array}{l}\text { Shibgonj, } \\
\text { Bogra }\end{array}$} & 5.7 & 1.4 & 1.9 & 0.43 & 0.14 & 0.06 & 22 & 12 & 0.4 & 0.8 & 0.7 \\
\hline & \multicolumn{10}{|c|}{$2009-2010$} & \\
\hline $\begin{array}{l}\text { Shibgonj, } \\
\text { Bogra }\end{array}$ & 5.9 & 1.5 & 2.00 & 0.46 & 0.14 & 0.05 & 25 & 11 & 0.3 & 0.7 & 0.7 \\
\hline Critical level & - & - & 2.00 & 0.50 & 0.12 & - & 7 & 10 & 0.2 & 1.0 & 0.6 \\
\hline
\end{tabular}

\section{Results and Discussion}

\section{Plant height}

It is clear from (Table 2) that the tallest coriander plant $(74.20 \mathrm{~cm}$ and $76.43 \mathrm{~cm})$ was recorded in treatment $\mathrm{T}_{10}\left(\mathrm{~N}_{70} \mathrm{P}_{50} \mathrm{~K}_{30} \mathrm{~S}_{20} \mathrm{~kg} / \mathrm{ha}\right)$ in both the years (2008-2009 and 2009-2010, respectively), while smallest plant was recorded in control. The similar results were reported by Vinay et al. (1999), Nwaduke and Chude (1995) and Ghobadi and Ghobadi et al. (2012).

\section{Number of primary branches per plant}

Table 2 revealed that maximum number of primary branches per plant (8.65) were found with the application of $\mathrm{N}_{70} \mathrm{P}_{50} \mathrm{~K}_{30} \mathrm{~S}_{20} \mathrm{~kg} / \mathrm{ha}$, while minimum number of primary branches per plant (3.35) in the control in the year 2009-2010 was significantly different. On the other hand, in the year 2008-2009 primary branches per plant did not vary significantly. It was observed that the number of primary branches per plant had contributed to seed yield. Thus, these parameters could be used as indicators of improving yield potential in coriander. These results are in accordance with the research findings of Nwaduke and Chude (1995 and Bhat et al. (1992).

\section{Number of umbels per plant}

Number of umbels per plant (Table 3) differed significantly due to application of nutrient element. Maximum number of umbel per plant (39.37 and 41.94) were found with the application of $\mathrm{N}_{70} \mathrm{P}_{50} \mathrm{~K}_{30} \mathrm{~S}_{20} \mathrm{~kg} / \mathrm{ha}$, while minimum number of umbels per plant in control in the year 2008-2009 and 2009-2010, respectively. This was probably due to the availability of more nutrient elements to plant at which plant could develop more and could produce more branches resulting in more number of umbels per plant. Aly (2002) also obtained similar results. 
Table 2. Effect of nitrogen, phosphorus, potassium, and sulphur on the vegetative growth of coriander during rabi seasons of 2008-2009 and 2009-2010

\begin{tabular}{c|l|l|l|l}
\hline \multirow{2}{*}{ Treatment } & \multicolumn{2}{c|}{ Plant height $(\mathrm{cm})$} & \multicolumn{2}{c}{$\begin{array}{c}\text { Number of primary branches/ } \\
\text { plant }\end{array}$} \\
\cline { 2 - 5 } & \multicolumn{1}{c}{$2008-2009$} & $2009-2010$ & $2008-2009$ & $2009-2010$ \\
\hline $\mathrm{T}_{1}\left(\mathrm{~N}_{0} \mathrm{P}_{50} \mathrm{~K}_{60} \mathrm{~S}_{20}\right)$ & $61.17 \mathrm{bcd}$ & $62.13 \mathrm{c}$ & 5.75 & $5.57 \mathrm{c}$ \\
$\mathrm{T}_{2}\left(\mathrm{~N}_{40} \mathrm{P}_{50} \mathrm{~K}_{60} \mathrm{~S}_{20}\right)$ & $62.13 \mathrm{bc}$ & $63.12 \mathrm{c}$ & 6.67 & $7.15 \mathrm{~b}$ \\
$\mathrm{~T}_{3}\left(\mathrm{~N}_{70} \mathrm{P}_{50} \mathrm{~K}_{60} \mathrm{~S}_{20}\right)$ & $66.73 \mathrm{~b}$ & $69.61 \mathrm{~b}$ & 6.40 & $7.05 \mathrm{~b}$ \\
$\mathrm{~T}_{4}\left(\mathrm{~N}_{100} \mathrm{P}_{50} \mathrm{~K}_{60} \mathrm{~S}_{20}\right)$ & $64.53 \mathrm{bc}$ & $68.04 \mathrm{~b}$ & 6.87 & $7.20 \mathrm{~b}$ \\
$\mathrm{~T}_{5}\left(\mathrm{~N}_{70} \mathrm{P}_{0} \mathrm{~K}_{60} \mathrm{~S}_{20}\right)$ & $53.67 \mathrm{~d}$ & $54.33 \mathrm{~d}$ & 5.80 & $6.42 \mathrm{bc}$ \\
$\mathrm{T}_{6}\left(\mathrm{~N}_{70} \mathrm{P}_{25} \mathrm{~K}_{60} \mathrm{~S}_{20}\right)$ & $66.40 \mathrm{~b}$ & $69.19 \mathrm{~b}$ & 6.20 & $6.88 \mathrm{~b}$ \\
$\mathrm{~T}_{7}\left(\mathrm{~N}_{70} \mathrm{P}_{50} \mathrm{~K}_{60} \mathrm{~S}_{0}\right)$ & $56.40 \mathrm{~cd}$ & $57.21 \mathrm{~d}$ & 6.67 & $7.29 \mathrm{~b}$ \\
$\mathrm{~T}_{8}\left(\mathrm{~N}_{70} \mathrm{P}_{75} \mathrm{~K}_{60} \mathrm{~S}_{20}\right)$ & $65.33 \mathrm{~b}$ & $68.67 \mathrm{~b}$ & 6.13 & $6.87 \mathrm{~b}$ \\
$\mathrm{~T}_{9}\left(\mathrm{~N}_{70} \mathrm{P}_{50} \mathrm{~K}_{0} \mathrm{~S}_{20}\right)$ & $60.64 \mathrm{bcd}$ & $66.83 \mathrm{~b}$ & 5.97 & $6.36 \mathrm{bc}$ \\
$\mathrm{T}_{10}\left(\mathrm{~N}_{70} \mathrm{P}_{50} \mathrm{~K}_{30} \mathrm{~S}_{20}\right)$ & $74.20 \mathrm{a}$ & $76.43 \mathrm{a}$ & 7.23 & $8.65 \mathrm{a}$ \\
$\mathrm{T}_{11}\left(\mathrm{~N}_{70} \mathrm{P}_{50} \mathrm{~K}_{60} \mathrm{~S}_{10}\right)$ & $62.33 \mathrm{bc}$ & $63.30 \mathrm{c}$ & 6.60 & $6.94 \mathrm{~b}$ \\
$\mathrm{~T}_{12}\left(\mathrm{~N}_{70} \mathrm{P}_{50} \mathrm{~K}_{90} \mathrm{~S}_{20}\right)$ & $66.73 \mathrm{~b}$ & $69.62 \mathrm{~b}$ & 6.13 & $6.85 \mathrm{~b}$ \\
$\mathrm{~T}_{13}\left(\mathrm{~N}_{70} \mathrm{P}_{50} \mathrm{~K}_{90} \mathrm{~S}_{10}\right)$ & $63.84 \mathrm{bc}$ & $67.77 \mathrm{~b}$ & 6.13 & $6.41 \mathrm{bc}$ \\
$\mathrm{T}_{14}\left(\mathrm{~N}_{0} \mathrm{P}_{0} \mathrm{~K}_{0} \mathrm{~S}_{0}\right)$ & $47.07 \mathrm{e}$ & $47.18 \mathrm{e}$ & 3.85 & $3.35 \mathrm{~d}$ \\
\hline $\mathrm{CV}(\%)$ & 10.54 & 2.78 & 12.78 & 8.48 \\
\hline
\end{tabular}

Treatment means having common letter(s) are not significantly different from each other at $5 \%$ level of significant by DMRT.

\section{Number of capsules per plant}

Table 3 revealed that the maximum number of capsules per umbel (238.2) in the year 2009-2010 was observed when nutrient elements were applied in moderate dose in the treatment $\mathrm{N}_{70} \mathrm{P}_{50} \mathrm{~K}_{30} \mathrm{~S}_{20} \mathrm{~kg} / \mathrm{ha}$ and minimum in control. In year 20082009, number of capsules per plant did not vary significantly with various nutrient treatments. Total number of capsule per plant seems to be the most important component closely related with seed yield per plant and in turn yield per hectare. Increase in number of capsules per plant is due to production of more number of flowers per umbel, higher percentage of capsule set and reduced shedding of flowers and capsule and resulted in increased yield. Tripathi et al. (2001) also recorded similar results. 
Table 3. Effect of nitrogen, phosphorus, potassium, and sulphur on the reproductive growth and yield of coriander.

\begin{tabular}{|c|c|c|c|c|c|c|c|c|}
\hline \multirow{2}{*}{ Treatment } & \multicolumn{2}{|c|}{ No. of umbels/plant } & \multicolumn{2}{|c|}{ No. of capsules/plant } & \multicolumn{2}{|c|}{ 1000-seed wt (g) } & \multicolumn{2}{|c|}{ Yield of seeds (t/ha) } \\
\hline & 2008-09 & $2009-10$ & 2008-09 & $2009-10$ & 2008-09 & $2009-10$ & 2008-09 & $2009-10$ \\
\hline $\mathrm{T}_{1}\left(\mathrm{~N}_{0} \mathrm{P}_{50} \mathrm{~K}_{60} \mathrm{~S}_{20}\right)$ & $16.13 b$ & $19.83 \mathrm{ef}$ & 145.1 & $148.3 \mathrm{~g}$ & $5.61 \mathrm{~cd}$ & $5.60 \mathrm{bc}$ & $1.28 \mathrm{ef}$ & $1.30 \mathrm{~h}$ \\
\hline $\mathrm{T}_{2}\left(\mathrm{~N}_{40} \mathrm{P}_{50} \mathrm{~K}_{60} \mathrm{~S}_{20}\right)$ & $21.14 \mathrm{~b}$ & $25.56 \mathrm{~d}$ & 165.0 & $168.6 \mathrm{e}$ & $5.70 \mathrm{bcd}$ & $5.73 b c$ & $1.45 \mathrm{de}$ & $1.50 \mathrm{ef}$ \\
\hline $\mathrm{T}_{3}\left(\mathrm{~N}_{70} \mathrm{P}_{50} \mathrm{~K}_{60} \mathrm{~S}_{20}\right)$ & $26.01 \mathrm{~b}$ & $28.71 \mathrm{~b}$ & 179.2 & $180.4 d$ & $5.81 \mathrm{bc}$ & $5.90 \mathrm{abc}$ & $1.64 \mathrm{bcd}$ & $1.68 \mathrm{c}$ \\
\hline $\mathrm{T}_{4}\left(\mathrm{~N}_{100} \mathrm{P}_{50} \mathrm{~K}_{60} \mathrm{~S}_{20}\right)$ & $25.23 b$ & $26.03 \mathrm{~cd}$ & 175.2 & $178.1 \mathrm{~d}$ & $5.70 \mathrm{bcd}$ & $5.73 \mathrm{bc}$ & $1.57 \mathrm{bcde}$ & $1.56 \mathrm{de}$ \\
\hline $\mathrm{T}_{5}\left(\mathrm{~N}_{70} \mathrm{P}_{0} \mathrm{~K}_{60} \mathrm{~S}_{20}\right)$ & $20.13 b$ & $21.95 \mathrm{ef}$ & 150.1 & $158.3 \mathrm{c}$ & $5.37 \mathrm{~d}$ & $5.39 \mathrm{c}$ & $1.42 \mathrm{de}$ & $1.44 \mathrm{fg}$ \\
\hline $\mathrm{T}_{6}\left(\mathrm{~N}_{70} \mathrm{P}_{25} \mathrm{~K}_{60} \mathrm{~S}_{20}\right)$ & $38.60 \mathrm{a}$ & $40.94 \mathrm{a}$ & 195.1 & $198.3 \mathrm{c}$ & $6.00 \mathrm{ab}$ & $6.03 \mathrm{ab}$ & $1.79 \mathrm{bc}$ & $1.83 \mathrm{~b}$ \\
\hline $\mathrm{T}_{7}\left(\mathrm{~N}_{70} \mathrm{P}_{50} \mathrm{~K}_{60} \mathrm{~S}_{0}\right)$ & $17.29 \mathrm{~b}$ & $19.92 \mathrm{ef}$ & 220.2 & $223.6 \mathrm{~b}$ & $5.63 \mathrm{~cd}$ & $5.51 \mathrm{bc}$ & $1.35 \mathrm{de}$ & $1.38 \mathrm{~g}$ \\
\hline $\mathrm{T}_{8}\left(\mathrm{~N}_{70} \mathrm{P}_{75} \mathrm{~K}_{60} \mathrm{~S}_{20}\right)$ & $25.00 \mathrm{~b}$ & $28.28 \mathrm{bc}$ & 213.1 & $217.8 \mathrm{~b}$ & $5.80 \mathrm{bc}$ & $5.90 \mathrm{abc}$ & $1.51 \mathrm{cde}$ & $1.54 \mathrm{e}$ \\
\hline $\mathrm{T}_{9}\left(\mathrm{~N}_{70} \mathrm{P}_{50} \mathrm{~K}_{0} \mathrm{~S}_{20}\right)$ & $18.80 \mathrm{~b}$ & $19.48 \mathrm{f}$ & 194.7 & $196.9 \mathrm{c}$ & $5.60 \mathrm{~cd}$ & $5.87 \mathrm{abc}$ & $1.42 \mathrm{de}$ & $1.41 \mathrm{~g}$ \\
\hline $\mathrm{T}_{10}\left(\mathrm{~N}_{70} \mathrm{P}_{50} \mathrm{~K}_{30} \mathrm{~S}_{20}\right)$ & $39.37 \mathrm{a}$ & $41.94 \mathrm{a}$ & 233.9 & $238.2 \mathrm{a}$ & $6.03 \mathrm{ab}$ & $6.34 \mathrm{a}$ & $2.06 \mathrm{a}$ & $2.09 \mathrm{a}$ \\
\hline $\mathrm{T}_{11}\left(\mathrm{~N}_{70} \mathrm{P}_{50} \mathrm{~K}_{60} \mathrm{~S}_{10}\right)$ & $19.37 \mathrm{~b}$ & $20.37 \mathrm{ef}$ & 166.8 & $169.8 \mathrm{e}$ & $5.77 \mathrm{bc}$ & $5.96 \mathrm{abc}$ & $1.56 \mathrm{bcde}$ & $1.62 \mathrm{~cd}$ \\
\hline $\mathrm{T}_{12}\left(\mathrm{~N}_{70} \mathrm{P}_{50} \mathrm{~K}_{90} \mathrm{~S}_{20}\right)$ & $26.33 b$ & $26.29 \mathrm{bcd}$ & 157.7 & $159.4 \mathrm{f}$ & $5.73 b c$ & $5.84 \mathrm{abc}$ & $1.81 \mathrm{ab}$ & $1.80 \mathrm{~b}$ \\
\hline $\mathrm{T}_{13}\left(\mathrm{~N}_{70} \mathrm{P}_{50} \mathrm{~K}_{90} \mathrm{~S}_{10}\right)$ & $21.47 \mathrm{~b}$ & $22.37 \mathrm{e}$ & 154.0 & $156.3 \mathrm{f}$ & $5.80 \mathrm{bc}$ & $5.93 \mathrm{abc}$ & $1.50 \mathrm{cde}$ & $1.57 \mathrm{de}$ \\
\hline $\mathrm{T}_{14}\left(\mathrm{~N}_{0} \mathrm{P}_{0} \mathrm{~K}_{0} \mathrm{~S}_{0}\right)$ & $15.93 b$ & $16.06 \mathrm{~g}$ & 113.5 & $107.4 \mathrm{~h}$ & $4.20 \mathrm{e}$ & $4.17 \mathrm{~d}$ & $0.39 \mathrm{f}$ & $0.40 \mathrm{i}$ \\
\hline $\mathrm{CV}(\%)$ & 31.27 & 5.63 & 18.62 & 2.14 & 7.86 & 5.43 & 25.35 & 3.16 \\
\hline
\end{tabular}

Treatment means having common letter(s) are not significantly different from each other at $5 \%$ level of significant by DMRT. 


\section{0-seed weight (g)}

The effect of different levels of applied nutrient on 1000-seed weight of coriander was statistically significant (Table 3 ). The maximum weight of 1000 seed (6.03g in 2008-2009 and 6.34g in 2009-2010) was recorded from $\mathrm{N}_{70} \mathrm{P}_{50} \mathrm{~K}_{30} \mathrm{~S}_{20} \mathrm{~kg} / \mathrm{ha}$ treatment, while, minimum 1000 value (4.20 g in 2008-2009 and $4.17 \mathrm{~g}$ in 2009-2010) noted in control. As the nutrient elements have a vital role in the seed development and hence, it has positively affected the seed weight up to the moderate dose of application. Vinay et al. (1999) also obtained 500seed weight with the highest nitrogen and phosphorus dose.

\section{Seed yield}

Seed yield is more important than total biological yield which results from different combinations of many physiological processes based on the environment under which the crop was grown. Seed yield depends upon production of photosynthates and their distribution among various plant parts. The synthesis, accumulation, and translocation of photosynthates depend upon efficient photosynthetic structure as well as source to sink relationship. In the present investigation, seed yield in coriander was influenced by the application of different nutrient elements (Table 3). The highest seed yield (2.06 t/ha in 20082009 and 2.09 t/ha in 2009-2010) was obtained in treatment $\mathrm{N}_{70} \mathrm{P}_{50} \mathrm{~K}_{30} \mathrm{~S}_{20} \mathrm{~kg} / \mathrm{ha}$ and minimum in control. The higher seed yield of coriander may be attributed to improved growth parameters and yield components which ultimately resulted in higher seed yield and also due to the supply of major nutrients and indirectly the physical condition of soil viz., aggregation, aeration, permeability, water holding capacity and biological condition of soil, which resulted in significantly higher seed yield. Similar results were in agreement with the findings of Nwaduke and Chude (1995), Singh et al. (1999), and Tripathi et al. (2001).

\section{Conclusion}

Nitrogen, phosphorus, potassium, and sulprur played an important role in increasing growth and seed yield of coriander. The fertilizer treatment $\mathrm{N}_{70} \mathrm{P}_{50} \mathrm{~K}_{30} \mathrm{~S}_{20}$ was observed to be the best suitable dose for coriander cultivation in Grey Terrace Soil of Amnura Soil Series under AEZ-25 of Bangladesh.

\section{References}

Aly, M.S. 2002. Effect of organic and mineral fertilization and their combination on Coriandrum sativum L. Minufia J. Agric. Res. 27(5): 1263-1274.

Bhat, V.R., G.S. Sulikeri and N.C. Hulamani. 1992. Effect of nitrogen, phosphorus and potassium on herbage yield of coriander. Spices India 5 (10): 11-13. 
Bhuiyan, N., J. Begum and M. Sultana. 2009. Chemical composition of leaf and seed essential oil of coriander (Coriandrum sativum L.) from Bangladesh. Bangladesh J. Pharmacology 4: 150-153.

Channabasavanna, A.S. 2002. Standardization and economic analysis of fertilizer levels for coriander (Coriandrum sativum L.). J. Maharstra Agric. University 27(2): 160-162.

Ghobadi, M.E. and M. Ghobadi. 2012. Effects of late sowing on quality of coriander (Coriandrum sativum L.). World Academy of Sci., Eng. Tech. 67: 432-435.

Gomez, K.A. and A.A. Gomez. 1984. Statistical procedures for Agricultural Research $\left(2^{\text {nd }}\right.$ Ed.). John Wiley and Sons, New York, USA, Pp. 28-92.

Hunter, A.H. 1984. Soil Analytical Services in Bangladesh. BARI/Aids Consultancy Report. Cotract Aid/388-005. Dhaka, Bangladesh. Pp. 1-7.

Jan, I., M. Sajid, A.H. Shah, A. Rab, N.H. Khan, F.I. Wahid, A. Rahman, R. Alam and H. Alam. 2011. Response of seed yield of coriander to phosphorus and row spacing. Sarhad J. Agric. 27(4): 549-552.

Luaza, G., R. Brevendan and Palomo. 1996. Coriander under irrigation in Argentina. In: Janick, J. (Ed) Progress in New Crops. ASHS Press, Arlington, VA. Pp. 590-594.

Nwaduke, P.O. and V.O. Chude. 1995. Effect of nitrogen and phosphors fertilization on seed crop of coriander in semiarid tropical soil. Tropical Agrics 72(3): 216-219.

Pruthi, J.S. 2001. Minor spices and condiments crop management and post-harvest technology. Indian Council of Agricultural Research. New Delhi. Pp. 158-161.

Rahman, M.J., R. Sen, M.M. Islam, S.A. Mallik and M.S. Khan. 2006. Effects of irrigation and fertilizer on the yield and yield components of coriander. Bangladesh J. Agril. Res. 31(10): 69-75.

Ramadan, F.M. and J.T. Morsel. 2002. Oil composition of coriander (Coriandrum sativum L.) fruit-seeds. Eur. Food Res. Technol. 215: 204-209.

Sharma, R.N. 1996. Effect of date of sowing and level of nitrogen and phosphorus on growth and seed yield of coriander. Bhartiya Drishi Anusandan Patrika 11(4): 232-238.

Singh, Vinay, R.K. Bisen and V. Singh. 1999. Response of nitrogen and phosphorus on seed crop of coriander. Environ. Eco. 17(1): 238-239.

Tripathi, A.K., R.K. Pandy and M.L. Tripathi. 2001. Effect of nitrogen, phosphorus and potassium on stem gall disease and yield of coriander. Ann. Plant Protection Sci. 9(2): 337-339.

Vinay, S., R.K. Bisen and V. Singh. 1999. Response of nitrogen and phosphorus on seed crop of coriander. Envirn. Ecol. 17(1): 238-239. 